University of Nebraska - Lincoln

DigitalCommons@University of Nebraska - Lincoln

Faculty Publications from the Harold W. Manter Laboratory of Parasitology

$4-1984$

\title{
The Taxonomic Status of Echinococcus cruzi Brumpt and Joyeux, 1924 (Cestoda: Taeniidae) from an Agouti (Rodentia: Dasyproctidae) in Brazil
}

\author{
Robert L. Rausch \\ University of Washington, rausch@uw.edu
}

A. D'Alessandro

Tulane University International Center for Medical Researc

M. Ohbayashi

Hokkaido University

Follow this and additional works at: https://digitalcommons.unl.edu/parasitologyfacpubs

Part of the Parasitology Commons

Rausch, Robert L.; D'Alessandro, A.; and Ohbayashi, M., "The Taxonomic Status of Echinococcus cruzi Brumpt and Joyeux, 1924 (Cestoda: Taeniidae) from an Agouti (Rodentia: Dasyproctidae) in Brazil" (1984). Faculty Publications from the Harold W. Manter Laboratory of Parasitology. 368.

https://digitalcommons.unl.edu/parasitologyfacpubs/368

This Article is brought to you for free and open access by the Parasitology, Harold W. Manter Laboratory of at DigitalCommons@University of Nebraska - Lincoln. It has been accepted for inclusion in Faculty Publications from the Harold W. Manter Laboratory of Parasitology by an authorized administrator of DigitalCommons@University of Nebraska - Lincoln. 


\title{
THE TAXONOMIC STATUS OF ECHINOCOCCUS CRUZI BRUMPT AND JOYEUX, 1924 (CESTODA: TAENIIDAE) FROM AN AGOUTI (RODENTIA: DASYPROCTIDAE) IN BRAZIL
}

\author{
R. L. Rausch, A. D'Alessandro, ${ }^{*}$ and M. Ohbayashi† \\ Division of Animal Medicine SB-42, University of Washington, Seattle, Washington 98195
}

\begin{abstract}
Paratype material of Echinococcus cruzi Brumpt and Joyeux, 1924, described from an agouti, Dasyprocta leporina (L.), in Brazil, was compared with Echinococcus oligarthrus (Diesing, 1863), of which the larval stage occurs also in agoutis and other rodents in South America and Central America. Comparisons of the larval cestodes (metacestodes) showed that the rostellar hooks from protoscolices of the two taxa corresponded in form, and their slightly greater lengths in $E$. cruzi were considered to be of no taxonomic significance. They agreed as well in other morphological characteristics. Echinococcus cruzi was compared also with the other neotropical species, $E$. vogeli Rausch and Bernstein, 1972. Based on these comparisons and in agreement with the earlier conclusion of Cameron (1926), E. cruzi Brumpt and Joyeux, 1924 is placed in synonymy with $E$. oligarthrus (Diesing, 1863).
\end{abstract}

Echinococcus cruzi Brumpt and Joyeux, 1924 appears to be the only nominal species of indeterminate status in the genus Echinococcus Rudolphi, 1801. The description of this taxon was based on the larval stage, which had been found in the liver and spleen of one of four agoutis, Dasyprocta aguti L. $[=D$. leporina $(\mathrm{L}$.); see Honacki et al., 1982, p. 576], collected at Albuquerque Lins, State of São Paulo, Brazil, in May 1914. Cameron (1926) considered E. cruzi to be the larval stage (metacestode) of E. oligarthrus (Diesing, 1863), of which the strobilar stage occurs in wild felids in Central America and South America. The designation E. cruzi was applied tentatively to larval cestodes from an agouti, $D a$ syprocta rubrata $[=D$. aguti cayana (Lacépède) (see Cabrera, 1961, p. 585)] (= D. leporina), and from a spiny rat, Echimys cayennensis trinitatus (= Proechimys sp.; see Honacki et al., 1982, p. 589 ), in Venezuela by Vogelsang and Barnola (1957) and López-Neyra and Díaz-Ungría (1958). In his monograph of the suborder Taeniata, Abuladze (1964, p. 340$)$ listed $E$. cruzi as the larval stage of $E$. oligarthrus. More recently, Sousa and Thatcher (1969) observed that the characteristics of the larval E. oligarthrus obtained experimentally by them in agoutis and other rodents closely resembled those described for $E$. cruzi. Szidat

Received 11 October 1983; revised 27 December 1983; accepted 28 December 1983.

* Tulane University International Center for Medical Research, Apartado Aéreo 5390, Cali, Colombia.

$\dagger$ Department of Parasitology, Faculty of Veterinary Medicine, Hokkaido University, Sapporo 060, Japan.
(1971) accepted the concept that $E$. cruzi is the larval stage of $E$. oligarthrus.

In 1955, the late Dr. G. E. Vogelsang, Universidad Central de Venezuela, sent one of us (RLR) two slides of tissue-sections, labelled Echinococcus cruzi, which he had received from Prof. E. Brumpt, with the information (in litt., 3 August 1955) that one of the slides contained sections of the type material, provided by Brumpt at the time $E$. cruzi was described. A preliminary study of the sections (by MO and RLR) was inconclusive, because comparative material was not available. With the subsequent description of another neotropical species, Echinococcus vogeli Rausch and Bernstein, 1972, and with definition of taxonomic characters that distinguish the larval stages of E. oligarthrus and E. vogeli, it became practicable to undertake comparisons to establish the taxonomic status of E. cruzi. The present paper reports the results of this study.

\section{MATERIALS AND METHODS}

The original material of $E$. cruzi as reported by Brumpt and Joyeux (1924) consisted of a single cyst in the spleen and three smaller cysts in the liver of the infected agouti. These had been sectioned serially for study (Brumpt and Joyeux, 1924, p. 226). The slide from the type-series sent by Dr. Vogelsang holds sections of three separate hepatic cysts, stained in hematoxylin-eosin, identified on the label, in handscript, as "Echinococcus cruzi Bru. 4/7 1924, Agouti 428 (III), Foie," and in the lower right corner is the numeral " 5 ," probably indicating the number of the slide in the series.

The second slide provided by Dr. Vogelsang contains a single section of larval Echinococcus sp. in spleen, stained apparently in orange $\mathrm{G}$-aniline blue. The label includes the printed designation "Fac. Med. Paris. E. C." at the top, and "Parasitologie" below, with a handwritten notation "Echinococcus cruzi" and the name 
"Curtis." The origin of this specimen is uncertain, although Brumpt evidently was aware of only a single agouti infected by $E$. cruzi. He later stated, with reference to the hosts of E. granulosus (Brumpt, 1949, p. 751 , footnote), that "L'Agouti (Dasyprocta aguti) avait été ajouté par A. Lutz à cette liste d'hôtes. J'ai retrouvé un cas d'infestation de cet animal, au Brésil, en 1913 [sic]: il s'agit d'une autre espèce: Echinococcus cruzi.",

Dr. Vogelsang provided in addition a vial containing numerous specimens of Echinococcus $\mathrm{sp}$. obtained experimentally in dogs that had received cysts from an agouti, Dasyprocta rubrata $(=D$. leporina), collected at Rancho Grande, Estado Aragua, Venezuela. The dogs were examined three months after exposure, when they died (Vogelsang, in litt.). The infected agouti was mentioned by Vogelsang and Barnola (1957, p. 159): "Sur un rongeur (Dasyprocta rubrata) nous avons relevé des échinocoques du foie qui nous fit penser à l' $E$. cruzi décrit par E. Brumpt pour ce rongeur du Brésil." For our study, additional material from Brazil was provided by Dr. Paul C. Beaver, as follows: cysts from the liver of an agouti, Dasyprocta sp., 12 August 1960, $92 \mathrm{~km}$ from Belem; a single, intact cyst from the liver of a paca, Cuniculus paca L., 12 July 1964, Serra do Navio, Amapa; and liver of paca with tissues of larval cestodes, much autolyzed, 19 July 1964, at the latter locality. Dr. Beaver also made available tissues from an agouti, Dasyprocta punctata Gray, from Achiote, Colon Province, Panama, naturally infected by the larval $E$. oligarthrus.

In addition to the materials listed above, we compared larval stages of Echinococcus spp. studied previously (Rausch et al., 1978, 1981), as follows: $E$. oligarthrus-(1) from a laboratory mouse, Mus musculus L., infected experimentally (by AD'A) with eggs from cestodes in a naturally infected jaguarundi, Felis yagouaroundi Geoffroy, purchased in Villavicencio (Department of Meta), Colombia; (2) from a naturallyinfected spiny rat, Proechimys cf. guyannensis (Geoffroy), collected at Finca las Tigras, Vereda Vista Hermosa, Municipio San Juan de Arama (Dept. Meta); and (3) from a naturally-infected paca collected near Carimagua, Municipio de Puerto Lopez (Dept. Meta). $E$. vogeli-(1) from a case of polycystic hydatid disease in a patient from eastern Colombia (strobilar stage reared in dog by AD'A); (2) from a naturally-infected paca collected near Carimagua (strobilar stage reared in dog by AD'A); (3) from numerous naturally-infected pacas collected in the vicinity of Carimagua; and (4) from laboratory mice, gerbils, Meriones unguiculatus Milne-Edwards, and nutrias, Myocastor coypus (Molina), infected experimentally at the University of Washington (original material from three naturallyinfected pacas collected near Carimagua).

Protoscolices from larvae were stained in acetic carmine, processed by standard methods, and mounted permanently, with application of sufficient pressure to the cover-glass to disperse the rostellar hooks and to cause them to lie flat. Sections of cysts in situ, stained in hematoxylin-eosin or by the periodic acid-Schiff method, were those utilized in earlier studies (Rausch et al., 1978, 1981). For preparation of figures, the rostellar hooks were photographed at $\times 1,000$, and uniformly enlarged prints were made, from which the outlines were traced.

Measurements below are in micrometers unless otherwise stated.

\section{RESULTS}

\section{Characteristics of type material}

In the description of their findings in the infected agouti, Brumpt and Joyeux (1924, p. 226) stated that "Le foie montrait trois petits kystes, dont deux sclérosés et un de structure analogue à celle de la rate." The slide studied by us contained sections of three discrete vesicles, each in situ in a separate piece of liver, and measuring about $6 \times 5 \mathrm{~mm}, 5 \times 4 \mathrm{~mm}$, and $3 \times 2.8 \mathrm{~mm}$. Adjacent to the smallest was another vesicle, about $1.6 \times 0.8 \mathrm{~mm}$.

The liver exhibited a mild periportal hepatitis, but otherwise was normal. Each vesicle was surrounded externally by an adventitia that ranged in thickness from about 100 to 700 , but was thinnest at the hepatic surface, where portions of the vesicles were exposed immediately below Glisson's capsule. Externally, the capsule exhibited focal areas of infiltration by lymphocytes and plasma cells. The adventitia consisted of dense collagen, of which the fibers were mostly arranged concentrically. Fibroblasts were comparatively few, usually flattened, and more numerous toward the outer layers of the adventitia, the external surface of which was relatively smooth and distinctly set off from the adjacent hepatic tissue (Fig. 1). Often, at this junction, the adventitia was infiltrated by leukocytes, typically distributed in a linear pattern and, in order of decreasing numbers, consisting of eosinophils, plasma cells, and histiocytes (Fig. 2). Focal aggregations of eosinophils were sometimes present at the periphery of the adventitia. Also at the periphery, enclosed bile ducts were present, either

Figures 1-6. Characteristics of Echinococcus cruzi (paratype material). 1. Junction of adventitia with hepatic tissue. Darkly stained material at bottom consists of degenerating eosinophils. 2. Accumulation of leukocytes (predominantly eosinophils) at junction of adventitia with hepatic tissue. 3. Laminated membrane (arrow). 4. Germinal layer (arrow). 5. Brood capsules at periphery of vesicle. 6. Section of protoscolex, showing large rostellar hooks in situ. 


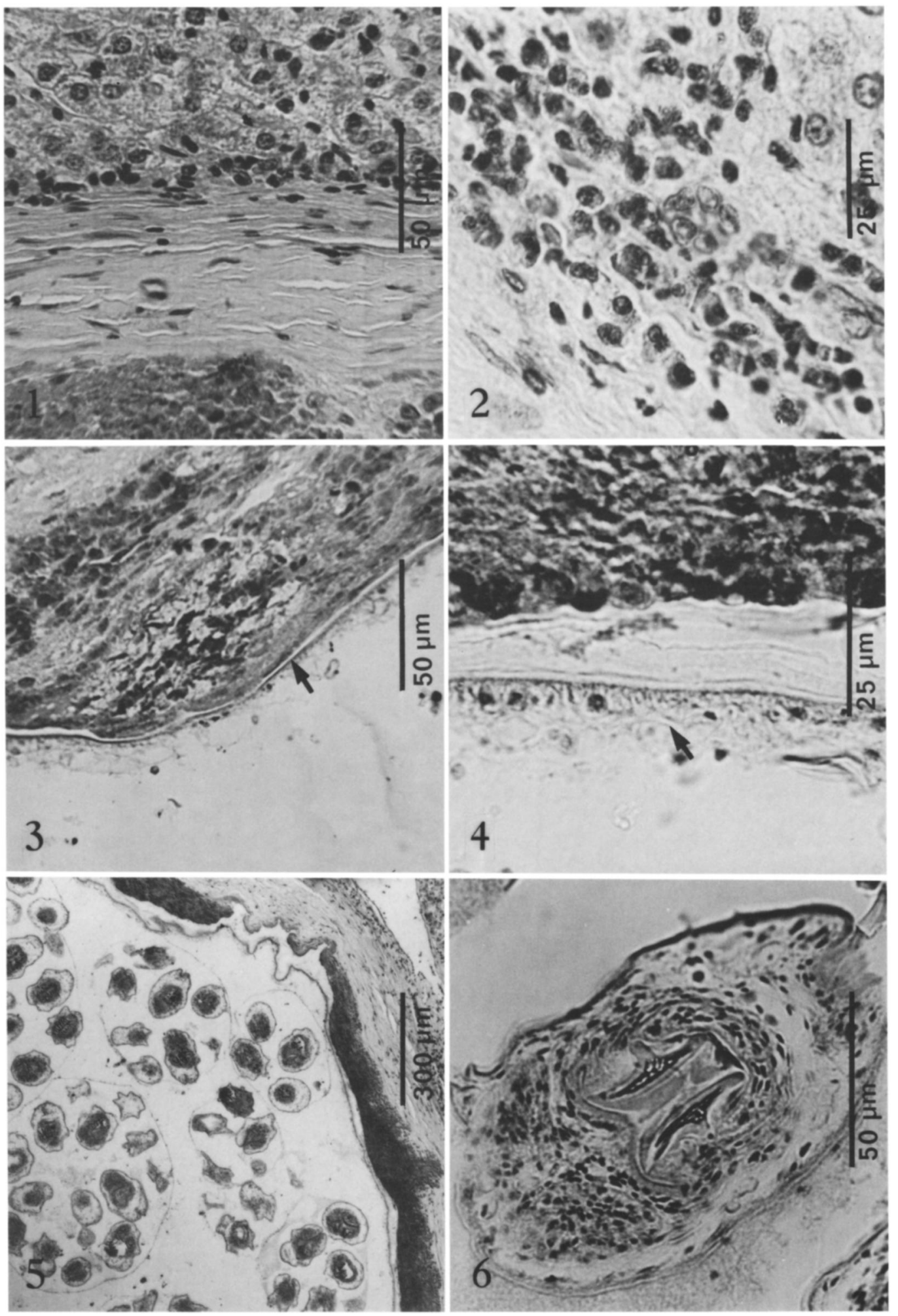


singly or in aggregations that apparently had arisen through hyperplasia. The inner surface of the adventitia was irregular, because of an uneven layer of necrotic cells interposed between it and the laminated membrane of the larval cestode. This layer, ranging from about 40 to more than 400 in thickness, was composed of degenerating leukocytes, mostly or entirely eosinophils. The boundary between the layer of degenerating cells and the fibrous tissue was usually distinct; occasionally, the mass of necrotic cells was confluent with small, focal areas of necrosis within the adventitia.

The laminated membrane of the cyst-walls was thin and uniform, usually ranging in thickness from about 2 to 7 (Fig. 3), and underlain by a granular, eosinophilic layer, about 1 in thickness, of undetermined composition. Proliferation of laminated membrane into the lumina of the vesicles was not observed. The germinal layer was well developed, and ranged from about 5 to 12 in thickness (Fig. 4). It was separated from the underlying laminated membrane by a thin basal layer, about 1 in thickness. Nuclei, 3 to 4 in diameter, were distributed throughout the germinal membrane, where remains of calcareous corpuscles were visible, mainly in its inner portion. Brood capsules arose from the germinal membrane, and usually were contiguous peripherally. These contained numerous protoscolices, none of which exhibited degenerative changes (Fig. 5). In most of the protoscolices, particularly at the proximal end, calcareous corpuscles were visible. Reliable measurements of the protoscolices could not be obtained from the sectioned material; their dimensions were given as 160 to 180 in length by 100 to 110 in width by Brumpt and Joyeux (1924, p. 226). Lengths of the large rostellar hooks ranged from 37 to $40(\bar{x}=38.2$, $n=42)$; of small hooks, 30 to $34(\bar{x}=32.3, n=$ 36) (Fig. 6).

The slide (paratype of $E$. cruzi) prepared by Prof. Brumpt has been deposited in the Helminthological Collection of the U.S. National Museum, No. 78003.

\section{Other material from Brazil}

The specimen in spleen, of unknown origin but possibly part of the type material, was similar to that described above and will not be considered here in detail. The rostellar hooks were identical in form and similar in size (50 each of large and small hooks measured); large hooks ranged in length from 35 to $40(\bar{x}=38.5)$, and small hooks, from 30 to $34(\bar{x}=32)$.

The specimen obtained from the agouti collected near Belem also was similar to $E$. cruzi; it was reported as $E$. oligarthrus by D'Alessandro et al. (1981, Table 2). An intact vesicle from the liver of this animal was somewhat irregular in shape, and measured about $16 \times 12 \mathrm{~mm}$ in maximum dimensions. From sections, it was evident that it represented a long-standing infection, as indicated by degenerative changes (focal necrosis, with calcification); findings otherwise did not differ significantly from those described above for the paratype material of E. cruzi. Formalinfixed protoscolices, measured without pressure, ranged from 130 to 160 in length by 100 to 120 in diameter (avg. of 50:153 × 110). The rostellar hooks were indistinguishable from those of $E$. cruzi. Large hooks ranged in length from 37 to $40(\bar{x}=38.1, n=24)$; small hooks, 29 to $32(\bar{x}=$ $30.4, n=16)$.

The two pacas collected at Serra do Navio were infected by $E$. vogeli. From one, an intact cyst in hepatic tissue was ovoid, measuring about $20 \times$ $14 \times 7 \mathrm{~mm}$, and contained numerous secondary vesicles, but brood capsules were few. Abundant protoscolices were present in the autolyzed material from the second animal. In both, characteristics of the rostellar hooks permitted unequivocal determination of the species.

Echinococcus sp. was reported from an agouti in Brazil by Lutz (1907), but the information provided is not sufficient to identify the species.

The cestodes reared in dogs by Vogelsang, from larvae (metacestodes) tentatively identified as $E$. cruzi from an agouti in Venezuela (Vogelsang and Barnola, 1957), were determined to be $E$. vogeli.

\section{Comparisons}

Three species of the genus Echinococcus are known to occur in South America. Of these, $E$. oligarthrus and $E$. vogeli are indigenous, whereas E. granulosus (Batsch, 1786) seems certainly to have been introduced with domestic animals from Europe (Rausch, 1967). These three species, in the strobilar stage, are distinguished by various morphological characteristics of taxonomic significance; in the larval stage, size, or form of rostellar hooks from protoscolices provide the most practicable means for separating the species. Echinococcus granulosus need not be considered further here. With respect to the identity of $E$. 

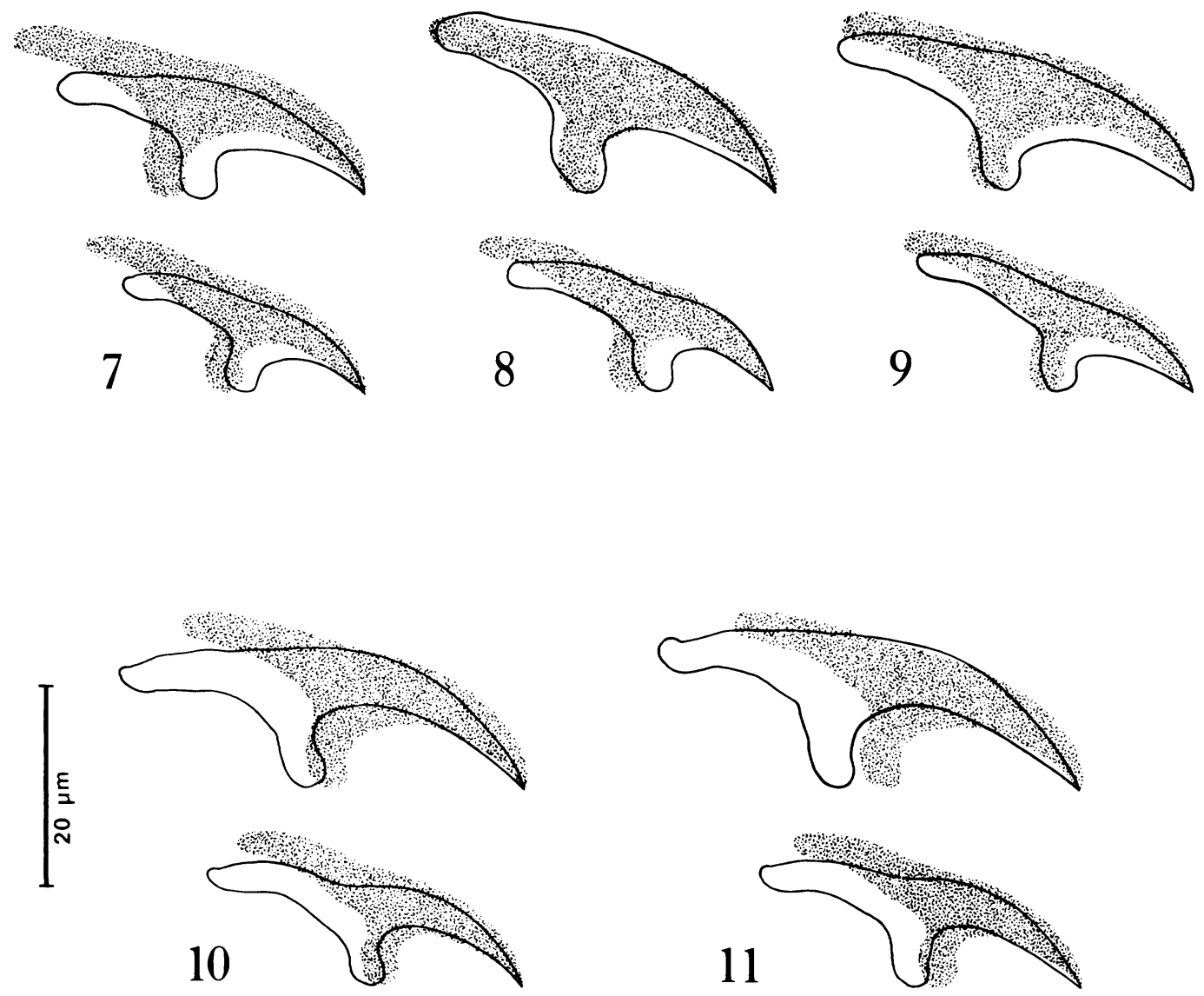

FIGURES 7-11. Large and small hooks of Echinococcus cruzi (shaded) of mean lengths (38 and $32 \mu \mathrm{m}$, respectively) superimposed on hooks from protoscolices of $E$. oligarthrus and $E$. vogeli (outlines). 7. Hooks of $E$. oligarthrus, of mean lengths for the species (32 and $26 \mu \mathrm{m}$, respectively), from experimentally infected laboratory mouse. 8. Hooks of $E$. oligarthrus, of near maximum lengths recorded for the species (37 and 29 $\mu \mathrm{m})$, from naturally-infected spiny rat, Colombia. 9. Hooks of mean lengths ( 38 and $30 \mu \mathrm{m})$ from larval cestode in naturally-infected agouti, vicinity of Belem, Brazil. 10. Hooks of $E$. vogeli, of mean lengths for the species (42 and $33 \mu \mathrm{m}$ ), from naturally-infected paca, Colombia. 11. Hooks of $E$. vogeli, of near maximum lengths for the species (44 and $34 \mu \mathrm{m})$, from experimentally infected gerbil.

cruzi, we recognized two possibilities-either it was the larval stage of $E$. oligarthrus, as sometimes has been assumed, or it represented an independent species of which the strobilar stage is unknown.

Based on the description by Brumpt and Joyeux (1924) and on our findings in naturally-infected rodents, $E$. cruzi and the larval $E$. oligarthrus have similar morphological characteristics: the laminated membrane is thin and uniform and does not proliferate within the lumen of the vesicle; the germinal membrane is relatively thick, with a well defined basal layer in which the elements tend to have a vertical arrangement; brood capsules are abundant and typically contiguous, forming a peripheral layer in the vesicle. The size of brood capsules in $E$. cruzi is not precisely known. Brumpt and Joyeux (1924) reported that protoscolices ranged from 160 to 180 in length by 100 to 110 in diameter, and thus were only slightly larger than those from the agouti from the vicinity of Belem (130-160 × 100-120). Protoscolices of $E$. oligarthrus from northern South America were similar in size, ranging from 125 to 163 in length by 95 to 142 in diameter (Rausch et al., 1981). The dimensions of protoscolices depend to some extent on their state of contraction, and may be influenced by methods of preservation.

Echinococcus cruzi differs ostensibly from the 


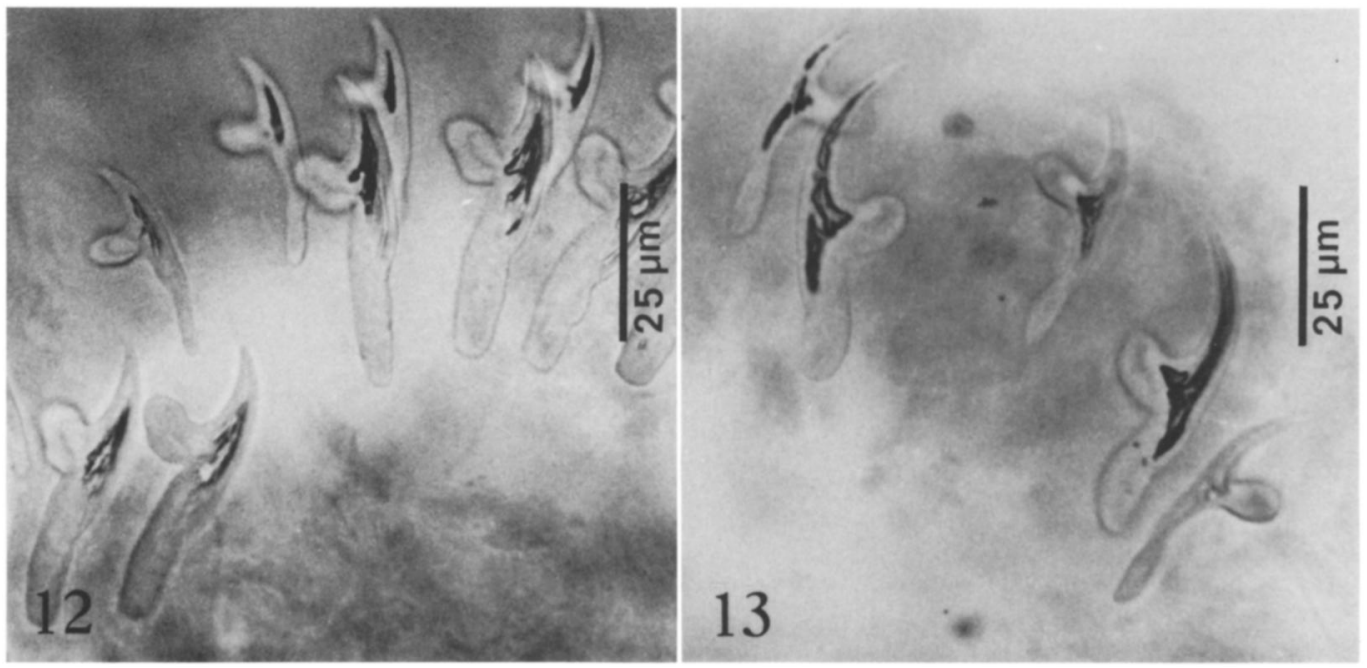

Figures 12, 13. Rostellar hooks from strobilar stage of Echinococcus spp. from a dog, Colombia. 12. E. oligarthrus. 13. E. vogeli.

larval $E$. oligarthrus in having rostellar hooks of greater length. For $E$. cruzi, Brumpt and Joyeux (1924) reported the lengths of large and small hooks to be 38 and 30, respectively. Our findings in the paratype material were similar: large hooks 37 to 40 , with an average of 38 ; small hooks, 30 to 34 , with an average of 32 . The dimensions of the cestode from the agouti collected near Belem also were similar: large hooks, 37 to 40 , with an average of 38; small hooks, 29 to 32, with an average of 30 . Thus, the rostellar hooks of $E$. cruzi and the other specimens from Brazil had lengths somewhat intermediate to those of $E$. oligarthrus and $E$. vogeli. No overlap in lengths of rostellar hooks of the two latter species was observed in material from northern regions of South America (Rausch et al., 1978, Table 2).

Based on material from Panama and northern South America, it was found that the rostellar hooks of $E$. oligarthrus and $E$. vogeli exhibit species-specific differences in form in both the larval and strobilar stages (Rausch et al., 1978, Figs. 1, 2). As shown by Brumpt and Joyeux (1924, Fig. 4), and confirmed in the paratype material, the hooks of $E$. cruzi are like those of E. oligarthrus in their proportions (Figs. 7-9). Brumpt and Joyeux (1924, p. 229) pointed out that the perpendicular guard "... divise le crochet en deux parties sensiblement égales." This statement well describes the large rostellar hooks, and applies equally to $E$. cruzi and $E$. oligar- thrus. The distinctive proportions of the hooks of $E$. vogeli are evident (Figs. 10, 11). The changes brought about by growth of the guard and handle of hooks in the final host do not obscure the fundamental differences in the shape of hooks in E. oligarthrus and $E$. vogeli (Figs. 12, 13). Other morphological characteristics that distinguish the larval stages of these cestodes have been described elsewhere (Rausch et al., 1981).

Our findings indicate that rostellar hooks of $E$. cruzi are only slightly longer than those of $E$. oligarthrus. Based on data for other taeniid cestodes, the greater lengths of hooks would not appear to exceed the expected limits of infraspecific variation.

\section{DISCUSSION}

Brumpt and Joyeux (1924) did not overlook comparison of the rostellar hooks of $E$. cruzi with those of the strobilar stage of $E$. oligarthrus, as redescribed by Lühe (1910), but they perhaps did not consider sufficiently the changes that take place in the guard and handle after ingestion of the larval cestode by the final host. They remarked (p. 230): "Toutefois les crochets dessinés par Lühe sont très différents de ceux de notre larve; ceux de la première et de la deuxième rangée présentent un dimorphisme plus nettement marqué que dans notre échinocoque. Enfin les dimensions ne sont pas les mèmes. Les grands crochets de $T$. oligarthra ont $47 \mu$, les petits 32 
$\mu$ de longueur totale. Il n'y a donc, pas de rapport entre ce cestode et la forme que nous décrivons." Cameron (1926) compared the hooks of E. cruzi, as described by Brumpt and Joyeux, with those of the strobilar stage of E. oligarthrus, and concluded that these cestodes were conspecific. He remarked (p. 18) that "A comparison with Brumpt and Joyeux's figures of the Hydatid and those of the adult worm (fig. 2, a) shews that the blade is identical in both cases and that the differences are due entirely to the extra growth of the guard and handle. Examination of the hooks of adult and Hydatid of E. granulosus shews that the growth is greater in the case of the large hooks than in the small, and that consequently the size dimorphism is much more marked in adults than in larvae. Moreover, in a very immature form of $E$. oligarthra examined by the writer, the hooks are found to correspond very closely to those of E. cruzi." Cameron's specimens of E. oligarthrus, which were also studied by Rausch and Bernstein (1972), were obtained from a jaguarundi captured in Central America (T. W. M. Cameron, pers. comm.).

Evidently, species-specific differences in extent of growth of the guard and handle of hooks exist in cestodes of the genus Echinococcus in the final host. Rausch (1953) observed that protoscolices of $E$. granulosus, from larvae from the lungs of moose, Alces alces (L.), had rostellar hooks that averaged 30 and 25 , whereas the strobilar stage, reared experimentally in dogs, had hooks with mean lengths of 38 and 30 . In E. multilocularis Leuckart, 1863, protoscolices from voles, $M i$ crotus oeconomus (Pallas), had rostellar hooks with mean lengths of 27 and 23; in strobilae reared experimentally in arctic foxes, Alopex lagopus (L.), the hooks had mean lengths of 27 and 22. Similar observations were reported by Vogel (1957), who remarked (p. 429): "Wenn man den Grössenzuwachs der Häkchen während der Entwicklung des larvalen Scolex zu dem des graviden Bandwurmes bei E. multilocularis und bei E. granulosus vergleicht, so fällt auf, dass die multilocularis-Häkchen nur wenig (etwa um 13\%) an Länge zunehmen, die granulosus-Häkchen von Schweinen hingegen deutlich mehr (etwa um 30\%)."

Based on average values obtained for cestodes collected in Colombia, the large hooks from protoscolices of $E$. oligarthrus were only about $57 \%$ as long as those from the strobilar stage, while the large hooks of $E$. vogeli were of about $77 \%$ of the final length; for small hooks, the respective values were about $67 \%$ and $77 \%$ (Rausch et al., 1978). In both species, the changes that occurred in the final host, less marked in E. vogeli, involve lengthening of the handle and enlargement of the guard. The differences in the shape of the blades in the hooks from protoscolices of the two species persist in the respective strobilar stages. Figures 12 and 13 show fully-developed hooks of $E$. oligarthrus and E. vogeli, obtained post mortem from a dog at Carimagua, Colombia. This animal, owned by a hunter, had been fed the viscera of pacas and other rodents. The hooks of $E$. oligarthrus had attained full development in the dog. The strobilae, however, were undeveloped; this cestode, occurring typically in felids, does not appear to be capable of producing eggs in canids (Sousa and Thatcher, 1969).

In the larval stage, mean lengths of rostellar hooks of Echinococcus spp. are influenced not only by intraspecific variation, but also by the state of development of protoscolices. The age of the larval cestode is one factor, but continuous production of protoscolices may occur at any age, resulting in a considerable range in lengths of rostellar hooks within a single brood capsule. Whereas hooks obviously immature are distinguishable, those still growing that have attained typical form may be included in series of measurements. Consequently, the resulting bias may be toward a lowering of mean dimensions. It is not now possible to account for the greater mean lengths of rostellar hooks in E. cruzi and in the larval cestode from the agouti collected near Belem, but the maximum lengths as compared with those obtained for $E$. oligarthrus farther north in South America (see Fig. 8) do not appear to exceed the expected limits of intraspecific variation in a single species. Comparable differences have been observed in rostellar hooks of $E$. granulosus and $E$. multilocularis from various localities.

We conclude, in agreement with Cameron (1926), that the description of Echinococcus cru$z i$ Brumpt and Joyeux, 1924 was based on the larval stage of $E$. oligarthrus (Diesing, 1863), of which the type material was collected by Johann Natterer from a cougar, Felis concolor $\mathrm{L}$., in Brazil. Echinococcus cruzi Brumpt and Joyeux, 1924 is therefore placed in synonymy with $E$. oligarthrus (Diesing, 1863).

\section{ACKNOWLEDGMENTS}

This work was supported in part by Grant AI 15172-04 from the Institute of Allergy and In- 
fectious Diseases, National Institutes of Health. Dr. Paul C. Beaver, Department of Tropical Medicine, Tulane University, provided materials and read a draft of the manuscript. Mrs. V. R. Rausch, University of Washington, prepared the figures. These contributions are gratefully acknowledged.

\section{LITERATURE CITED}

Abuladze, K. I. 1964. Teniaty-Lentochnye gel'minty zhivotnykh i cheloveka i vyzyvaemye imi zabolevaniia. Osnovy Tsestodologii, Vol. 4. Nauka, Moskva, 530 p.

Brumpt, E. 1949. Précis de parasitologie. Vol. 1. Masson, Paris, 1042 p.

— AND Ch. Joyeux. 1924. Description d'un nouvel échinocoque: Echinococcus cruzi n. sp. Ann. Parasitol. Hum. Comp. 2: 226-231.

Cabrera, A. 1961. Catalogo de los mamiferos de America del Sur. II. Rev. Mus. Argentino de Ciencias Naturales "Bernardino Rivadavia," Cien. Zool. 4: 309-732.

CAmeron, T. W. M. 1926. Observations on the genus Echinococcus Rudolphi, 1801. J. Helminthol. 4: 13-22.

D'Alessandro, A., R. L. Rausch, G. A. Morales, S. Collet, AND D. ANGel. 1981. Echinococcus infections in Colombian animals. Amer. J. Trop. Med. Hyg. 30: 1263-1276.

Honacki, J. H., K. E. Kinman, And J. W. KoepPl (eds.). 1982. Mammal species of the world. Allen Press and Assoc. of Systematics Collections, Lawrence, Kansas, 694 p.

López-Neyra, C. R., AND C. DÍAz-Ungría. 1958. Cestodes de Venezuela. V. Cestodes de vertebrados Venezolanos (segunda nota). Noved. Cien., Ser. Zool., No. 23, 41 p.

LÜHE, M. 1910. Cystotänien südamerikanischer Feliden. Zool. Jahrb., Suppl. 12: 687-710.
LuTz, A. 1907. Observação de uma cotia infeccionada com echinococcus. Rev. Soc. Scient. São Paulo 2: 113-114.

RausCh, R. L. 1953. The taxonomic value and variability of certain structures in the cestode genus Echinococcus (Rud., 1801) and a review of recognized species. In Thapar commemoration volume, J. Dayal and K. S. Singh (eds.). Dept. Zool., Univ. Lucknow, India, pp. 233-246.

- 1967. On the ecology and distribution of Echinococcus spp. (Cestoda: Taeniidae), and characteristics of their development in the intermediate host. Ann. Parasitol. Hum. Comp. 42: 1963.

- AND J. J. BernSTEIN. 1972. Echinococcus vogeli sp. n. (Cestoda: Taeniidae) from the bush dog, Speothos venaticus (Lund). Z. Tropenmed. Parasitol. 23: 25-34.

, A. D'Alessandro, and V. R. Rausch. 1981. Characteristics of the larval Echinococcus vogeli Rausch and Bernstein, 1972 in the natural intermediate host, the paca, Cuniculus paca L. (Rodentia: Dasyproctidae). Amer. J. Trop. Med. Hyg. 30: 1043-1052.

- V. R. RAuSCh, AND A. D'Alessandro. 1978. Discrimination of the larval stages of Echinococcus oligarthrus (Diesing, 1863) and E. vogeli Rausch and Bernstein, 1972 (Cestoda: Taeniidae). Amer. J. Trop. Med. Hyg. 27: 1195-1202.

SousA, O. E., AND V. E. Thatcher. 1969. Observations on the life-cycle of Echinococcus oligarthrus (Diesing, 1863) in the Republic of Panama. Ann. Trop. Med. Parasitol. 63: 165-175.

SzIDAT, L. 1971. Neue Aspekte des EchinococcenProblems. Angew. Parasitol. 12: 133-143.

Vogel, H. 1957. Über den Echinococcus multilocularis Süddeutschlands. I. Das Bandwurmstadium von Stämmen menschlicher und tierischer Herkunft. Z. Tropenmed. Parasitol. 8: 404-454.

Vogelsang, E. G., AND J. BARnOla. 1957. Le problème de l'hydatidose au Venezuela. Arch. Internac. Hidatidosis 16: 159-160. 